\section{The effect of consumption motivation on the perception of gift store attributes in jewelry retail stores and its influence on repurchase intention}

\author{
Ana Cristina Munaro' \\ Elaine Martins ${ }^{1}$ \\ Heitor Takashi Kato ${ }^{1}$ \\ ${ }^{1}$ Pontifical Catholic University of Paranal PUCPR, Postgraduate \\ Program in Administration (PPAD), Curitiba, Brazil
}

Received on

$10 / 17 / 2018$

Approved on

06/14/2019

\section{Responsible editor:}

Prof. Dr. Guilherme de farias

Shiraishi

Evaluation process:

Double Blind Review

\begin{abstract}
Purpose - The study assesses the effect of hedonic and utilitarian motivations on the perception of atmosphere and service quality, on satisfaction, and on repurchase intention in a Brazilian retail chain of silver jewelers.
\end{abstract}

Design/methodology/approach - A mall-intercept survey of 160 consumers and a structural equation model analysis were conducted using the SmartPLS software. Also, the research data were subjected to partial least squares multigroup analysis (PLS-MGA).

Findings - In general, the store's display/layout and customer service significantly impacted the customer's satisfaction and repurchase intention. Utilitarian consumers showed greater satisfaction in stores with background music. Hedonic consumers showed a strong relationship between the store display/layout and the customer service, and also between satisfaction and repurchase intention, indicating that the satisfaction they encounter with the store's atmosphere and service leads to repurchase intention.

Originality/value - Hedonic and utilitarian consumers differ in the cognitive procedures that are activated while shopping. By offering a store atmosphere tailored to the customers' orientations and decisions, retailers can increase consumer satisfaction of both hedonic and utilitarian consumers. In theory, the study addresses consumer motivation theory within the retail atmosphere, specifically gift shops in the silver jewelry segment.

Keywords - Hedonic motivation. Utilitarian motivation. Store atmosphere. Gift store. Silver jewelry retail.

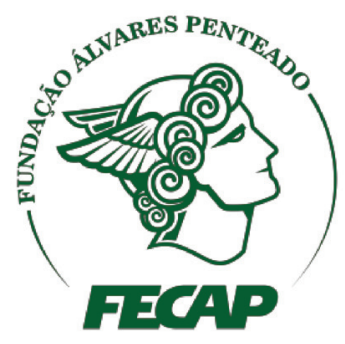

Review of Business Management

DOI: $10.7819 /$ rbgn.v21i5.4029 


\section{Introduction}

Growing numbers of shopkeepers are transforming their stores into pleasurable and stimulating shopping environments; that is, planned environments that create or reinforce consumer induction to purchase a product. Considering that satisfied consumers are more likely to stay with a company for longer periods and that behavioral intentions directly impact the company's profitability (Udo, Bagchi, \& Kirs, 2010), it is important for retailers to differentiate themselves by satisfying the needs of their consumers in a better way than their competitors (Dabholkar, Thorpe, \& Rentz, 1996).

The notion that the atmosphere influences consumer behavior is widely accepted in marketing literature (Turley \& Milliman, 2000). Consumers perceive service environments in a holistic way and their reactions to a physical environment depend on the set of effects or configurations (Lovelock \& Wirtz, 2011). In a servicescape, consumers examine the physical aspects of the service environment to compensate for the fact that service experience is intangible (Kotler, Ayes, \& Bloom, 2002; Singh, Katiyar, \& Verma, 2014). Nevertheless, the literature emphasizes the difficulty of measuring intangible and subjective aspects of a service environment (Grewal, Levy, \& Kumar, 2009).

Furthermore, decision-making styles are becoming increasingly complex for the process of consumers choosing a store, deciding to be satisfied with that decision, and then possibly making a purchase. Few studies have examined the structural relationship between the decisionmaking styles that consumers present during purchase, the level of satisfaction, and the purchase intention (Alavi, Rezaei, Valaei, \& Wan Ismail, 2015). First, one must consider which type of motivation leads consumers to a store and then to purchase. Is it hedonic or utilitarian? Based on this premise, many factors in the retail environment, including consumer service, must be tailored to assist the consumer's goal. Consumers' goals play an important role in determining how they perceive the retail environment and the various elements of the retail marketing mix (Grewal et al., 2009). These goals lead consumers to make their purchasing decisions and affect their satisfaction with the shopping experience. Specifically, purchase motivations affect the consumer needs, the search for information, and the assessment, acquisition, and post-purchase stages (Puccinelli et al., 2009).

Based on the aforementioned arguments, this study verifies how consumers perceive the retail atmosphere, starting by identifying the motivational aspect. More specifically, the study analyzes how the store atmosphere affects customer service, and how both aspects affect consumer satisfaction and repurchase intention. In evaluating the store atmosphere, the study considers variables such as cleanliness, music, temperature, lighting, color, display/layout, and scent. This study will address these variables within the context of a silver jewelry retailer, which has 65 outlets spread across different channels (streets and malls).

Therefore, this study attempts to verify whether the consumer's motivation (hedonic or utilitarian) changes the buying behavior in the retail space, and to better understand the role of store atmosphere and customer service as determinants of satisfaction and repurchase intention.

\section{Literature Review}

Buying motivation is an important influencer of consumer behavior (Haas \& Kenning, 2014), whether it is hedonic or utilitarian. A goal is defined as a cognitive representation of the desired end state (Barbopoulos \& Johansson, 2017). Thus, in addition to affecting the purchase, motivation tends to play a significant role in a customer's evaluation of a store's atmosphere (Ballantine, Jack, \& Parsons, 2010). In this context, Büttner, Florack, and Göritz (2013) suggest that marketers and retailers will benefit from addressing and evaluating consumers' buying orientations in the retail environment. If 
hedonic consumers (focused on the experience) and utilitarian consumers (focused on the task) differ in cognitive procedures that are activated while shopping, retailers can combine factors that make up the retail consumption environment to activate these cognitive procedures and enhance the proposed objectives.

The theoretical framework of this study discusses the motivators of consumption within the gift store environment for silver jewelry. In addition, this study evaluates customer service in the service environment and how it affects consumer responses (satisfaction and repurchase intention).

\section{I Store atmosphere and gift stores}

Bitner (1992) was the first to integrate empirical studies and theories about the store environment, creating the servicescape model. This model consists of a set of stimuli that is holistically perceived and commonly used when creating service environments. The author argues that the dimensions of the atmosphere create an integrated environment. This environment is moderated by the reactions of collaborators and consumers, who create internal responses that are affected by cognitive, emotional, and psychological factors. These responses guide consumers to approach or reject a store.

Ballantine et al. (2010) prove that consumers perceive a store's atmosphere holistically and their response to a physical environment depends on a set of effects, thus it is difficult to predict. For Singh et al. (2014), the attributes of a store's atmosphere and image of service personnel, that is, music, noise, room temperature, clothing and attitude of service personnel, etc. are considered by customers as critical factors. These are factors that heavily influence customer behaviors and display a significant positive correlation with customer approach behaviors. Bitner (1992) proposed a three-dimensional environmental model, composed of: a) environmental conditions: temperature, lighting, air quality, noise, music, odors, factors that affect the human senses; b) space/function: service environments that exist to fulfill specific consumer needs; c) signs, symbols, and artifacts: displayed internally and externally as a form of communication and signaling the store identity.

Turley and Milliman (2000) added two other categories of atmospheric variables, which are: 1) external variables: architecture, style, and stores around; and 2) human variables: characteristics of the employees, uniforms, accumulation of people, and private areas. Ortegón-Cortázar and Royo-Vela (2017) demonstrate the influence of the design and natural eco-environment on the intention to visit. This influence highlights the need for retailers to consider the relationship between a shopping center's design, environment, and ecological architecture, and consumers' behavior. Hence, the store atmosphere is a strategic element that must be built based on what the consumer values in a specific environment, in a holistic and integrated way, to gain a competitive advantage within the marketspace (Muhammad, Musa, \& Ali, 2014; Turley \& Chebat, 2002).

For Sheth, Mittal, and Newman (2001), the store atmosphere can stimulate the consumer to stay in the store or feel like leaving the place quickly. This shows that a store atmosphere has the ability to affect consumers not only cognitively but also emotionally (Muhammad et al., 2014). Since consumers perceive the retail atmosphere with their senses, it is a crucial aspect of the shopping process and behavioral responses (Doucé \& Janssens, 2013).

For instance, the background music increases sales and improves positive attitudes about the store (Chebat J., Chebat, \& Vaillant, 2001), affecting the length of stay and customer purchases (Yalch \& Spangenberg, 2000). Hussain and Ali (2015) found that cleanliness, smell, lighting, and store layout have a significant positive influence on consumers' purchase intention. In addition, the products at the point of sale should be displayed in a way that attracts consumers, 
having a strong impact on the purchase intention and the customer's perception regarding the product (Ballantine et al., 2010). Store displays are important sources of information for gift buying, that is, a wide selection and display of products is essential for gift buyers (Laroche, Saad, Kim, \& Browne, 2000a).

An important factor to consider when creating a store atmosphere is the type of product/ service that is being marketed. For example, for a gift shop, the environment must facilitate a vast product selection and easy-to-find goods. In an ethnographic study of gift shops in the Christmas period, Sherry and McGrath (1989) found that the store environment, from the structural design and decoration to the placement of objects and rearrangement strategies, delivers a powerful message to all who enter. The store experience is a gift and creates a persuasive environment.

Similar to Hussain and Ali (2015), this study has been designed to investigate the collective impact of all major atmospheric variables such as cleanliness, music, temperature, lighting, color, display/layout, and scent at one point in time. Given that consumer objectives play an important role in determining how consumers perceive the retail environment and the various elements of the retail marketing mix (Grewal et al., 2009), this study proposes:

H1a: Cleanliness has a significant impact on consumer satisfaction.

H1b: Music has a significant impact on consumer satisfaction.

H1c: Temperature has a significant impact on consumer satisfaction.

H1d: Color has a significant impact on consumer satisfaction.

H1e: Lighting has a significant impact on consumer satisfaction.

H1f: Display/layout has a significant impact on consumer satisfaction.
H1g: Scent has a significant impact on consumer satisfaction.

\subsection{Consumer service at a gift store}

In creating the servicescape model, Bitner (1992) proposed an intersection between the atmosphere, collaborators, and consumers. Since services are generally bought and consumed simultaneously (requiring human contact), collaborators and consumers both interact within the physical store environment. Hence, this environment must support the needs and preferences of both audiences. According to Ortegón-Cortázar and Royo-Vela (2017), the presence of uniformed employees and the appearance of the visitors themselves are both relevant variables regarding the physical environment.

Sharma and Stafford (2000) find that a store's atmosphere positively influences a customer's perception of attendants. Hence, the credibility of sellers and their persuasive power is impacted by the store's atmosphere. The influence of the store atmosphere on this perception has also been studied. One study finds that stores with a more prestigious image lead to a perception of higher quality care (Baker, Grewal, \& Parasuraman, 1994). Relational service arises from consumers' interactions with the service provider's staff. Superior relational service is characterized by service staff's courteous treatment of consumers, thoroughness of staff's explanations, and responsiveness to consumers' requests (Becerril-Arreola, Zhou, Srinivasan, \& Seldin, 2017). Thus, as consumer service is an integral part of the store atmosphere, this study proposes:

H2a: Cleanliness has a significant impact on consumer service.

H2b: Music has a significant impact on consumer service.

H2c: Temperature has a significant impact on consumer service. 
H2d: Color has a significant impact on consumer service.

H2e: Lighting has a significant impact on consumer service.

H2f: Display/layout has a significant impact on consumer service.

H2g: Scent has a significant impact on consumer service.

Schepers, Nijssen, and Heijden (2016) show that the notion of improving frontline employees is the missing link in studies that consider the relationship between role conflict and service performance. Ultimately, this provides individuals with (more) adequate solutions to deal with the problems they face. For Solomon (1988) and Turley and Milliman (2000), the appearance and uniform of the employees can directly affect the credibility and aesthetics of the store. The study by Singh et al. (2014) shows that a prompt service and an employee's knowledge affect the customer's buying pattern. To satisfy customers, stores need to deliver excellent service quality provided by customer-oriented salespeople. This will ultimately increase the likelihood of customers returning and recommending the shop to others.

Good service also contributes to a pleasant purchase and a positive evaluation of the store from both utilitarian and hedonically motivated customers (Teixeira \& Hernandez, 2012). Moreover, consumers attribute satisfying interactions with the service provider's staff to the management of the service provider (BecerrilArreola et al., 2017).

In addition, when it comes to purchasing a gift, the seller works on the issue of reducing perceived risk by making suggestions about what the recipient might like. They may also suggest more specific product information, such as the designer's status, possible colors, or matching accessories (Laroche et al., 2000a). For utilitarian buyers, the seller's performance is a facilitator within consumption, especially when the purchase time is short. The availability of information, time pressure, and a good selection positively affect the probability of a customer asking for a seller's assistance (Laroche, Saad, Browne, Cleveland, \& Kim, 2000b).

H3: The customer service has an influence on the customer's store satisfaction.

\subsection{Retail consumer responses: Satisfaction and repurchase intention}

For Dabholkar et al. (1996), retailers must differentiate themselves by seeking to satisfy their consumers' needs better than the competition. Given that satisfied consumers are more likely to stay with a company for longer periods, behavioral intentions directly influence a company's profitability (Udo et al., 2010). Cronin, Brady, and Hult (2000) indicated a relationship between quality, value, and satisfaction and consumer loyalty, positive word of mouth, premium prices, and repurchase intention.

Satisfaction can be defined as a judgment that a product or service receives. It is the feeling that the consumption provides to the customer and is a result of a pattern of pleasure versus displeasure (Oliver, 1999). Satisfaction is an important predictor of future behavior, because not only do satisfied consumers tend to buy the same brand in the same store but they are also less susceptible to competitors' offers and more likely to make positive comments to other people about the brand that they like. In the same way, dissatisfied consumers can influence the behavior of other individuals and damage a company's reputation. Becerril-Arreola et al. (2017) indicate that the service provider's emphasis on relational service satisfaction is positively related to service market share. In summary, consumer satisfaction is generally related to an increase in consumer loyalty, a reduction in price elasticity, a reduction in the costs of attracting new consumers, an increase in the company's reputation, and can 
act as a barrier to entry of new competitors (Blackwell, Miniard, \& Engel, 2005).

In addition to consumer satisfaction, retail managers crave results such as repurchase intention. Repurchasing, positive spontaneous references, and the ability to influence other consumers to experience the same brands, products, and services may be considered as evidence of loyalty (Ryu, Lee, \& Gon Kim, 2012). Loyalty is defined as a customer's commitment to returning to consume the same good or service (Oliver, 1999). Consumer satisfaction and loyalty, repurchase intention, and the intention to recommend an establishment (positive word of mouth) have been widely addressed as desired outcomes or effects of retail efforts (Teixeira $\&$ Hernandez, 2012).

For example, the study by Overby and Lee (2006) found that consumers consider utility and hedonic value as important factors for deciding between online stores. The study also found that utility motivational value is a stronger predictor than hedonic value. This finding is important given that previous in-store surveys have also supported the idea that utility and hedonic values are useful in predicting intention outcomes. Thus, consumer motivation plays an important role in purchasing preferences and, considering the fact that consumer satisfaction is directly correlated with customer intention, this study proposes:

\section{H4: Consumer satisfaction influences repurchase intention.}

\subsection{Consuming motivations and the store atmosphere}

Consumers shop for different reasons; sometimes shopping is a directed activity with a clear goal in mind (buying a product), at other times it is a recreational action and the fun is in the activity of going shopping itself (van Rompay, Tanja-Dijkstra, Verhoeven, \& van Es, 2012). The key to a better understanding of consumption may be found in the underlying motives that drive it (Barbopoulos \& Johansson, 2017).
Therefore, utilitarian and hedonic motivations are important influencers of consumer behavior (Haas \& Kenning, 2014). Utilitarian motivations reflect more rational purchase objectives, focused on the functionality or fulfillment of a task. Hedonic motivations are related to the consumer's emotions and experiences (Babin, Darden, \& Griffin, 1994; Büttner et al., 2013). In this sense, consumers with a utilitarian motivation appreciate when a product can be bought in a deliberate and efficient way; while those with a hedonic motivation appreciate the experience of purchasing (Doucé \& Janssens, 2013).

Utilitarian shopping is a means to an end. As this type of purchase does not seek pleasure, efficiency is important. Consumers see the purchase as a task that must be completed and try to complete it as efficiently as possible. Thus, aspects such as cleanliness, sales area, external appearance, variety of products exposed, lighting, and color are related to the variety of products and the ease of finding them. These can be considered as tangible attributes of the store (Ladeira, Nique, Pinto, \& Borges, 2016). The utilitarian is motivated by qualities such as safety, quality, function, and value for money. Consumers are also sensitive to variations in the cost and perceived value and pay less attention to emotional and social factors (Barbopoulos \& Johansson, 2017).

Hedonic buying may play positive and negative roles in relation to the benefits provided to the consumer in the buying experience; however, consumers with an experiential orientation try to explore different stimuli during purchases and can view buying as a pleasant task (Büttner et al., 2013; Teixeira \& Hernandez, 2012). According to Muhammad et al. (2014), hedonic experiences positively influence store loyalty. Hedonic motivation shows sub-goals such as pleasure, stimulation, and comfort, which means that utility and norms play a lesser role. This reduces the effectiveness of many behavioral change strategies, such as pricing strategies, incentives, and information campaigns (Barbopoulos \& Johansson, 2017). 
Consumer motivation can also affect the assessment of the atmosphere. The study by Ballantine et al. (2010) demonstrated that utilitarian consumers were happy in a hedonic environment; in contrast, a utilitarian environment evoked strong negative reactions from participants with a hedonic motivation. Thus, hedonic/experiential and utilitarian/ task-focused consumers differ in the cognitive procedures they activate during shopping. If retailers attempt to address both cognitive procedures, this could increase the range of tools that they can use to target consumer buying orientation (Büttner et al., 2013).

Ballantine et al.'s (2010) analysis revealed two categories of factors that seem to influence the hedonic experience of individuals: attractive and facilitating stimuli. The first one concerns signals that attract attention, excite the participant, and entice customers to approach. Critical success factors in creating a hedonic experience are: signs, sound, space, color, layout, product visualization, design features, and a pleasant scent (Doucé $\&$ Janssens, 2013). The second factor, facilitating stimuli, includes aspects that are necessary to facilitate product participation and exert a moderating influence on the effectiveness of attractive stimuli. This includes factors such as comforting features, overcrowding, lighting, and employees' presentation (Ballantine et al., 2010).

While consumers view shopping as a utilitarian task (e.g., finding a gift or a certain item), fulfilling the proposed task can also be enjoyable. When consumers refer to pleasant shopping experiences, they often describe situations in which they were able to buy products that were hard to find (Bäckström \& Johansson, 2006). Hence, the store layout can contribute to a positive experience when the store provides an environment where consumers can easily find the product they are looking for. Since time sensitivity is important in utilitarian situations, stores that can deliver a fast service are more likely to attract consumers that are looking to complete a particular task (Bäckström \& Johansson,
2006). Therefore, a store's tangible attributes have a strong positive impact on the value of the utilitarian product, and a store's intangible attributes have a positive impact on the hedonic product value (Ladeira et al., 2016).

Buying motivation is also linked to the recipient's good / service purchased and if the item purchased is for the buyer his/herself or for someone else. For Laroche et al. (2000a), the giftgiving process usually comprises a set of steps that includes a prior search for the gift, its exchange with the recipient, and subsequent consumption. Moreover, the reasons people exchange gifts are: (a) altruism, (b) economic reasons, (c) obligation, (d) social exchange, and (e) communication. For example, in the context of the Christmas gift ritual, the predominant motivation is a feeling of obligation and/or adherence to a cultural norm (Laroche et al., 2000b).

According to Ertimur and Sandikci (2005), there seem to be two presuppositions underlying the act of giving presents. First, there is a distinction between utilitarian and experiential gifts and a tacit understanding that utilitarian or experiential motives underlie gift giving and cannot operate simultaneously. Second, it seems that the symbolic value of the present is more important than its economic value, as the greater part of the value of the present stems from the thought and effort put into its selection.

However, for Huang (2007), while selfshoppers and gift buyers behave differently in their retail outlet options, both types of shoppers choose reputable stores. For Lee and Kim (2009), gift givers are generally more serious in the buying process, so they can avoid the potential costs and/or risks caused by their purchases, such as inaccurate delivery, inadequate product quality, and an unacceptable consumer service level (poor quality wrapping paper, restricted returns policy, etc.). As a result, consumers may wish to see and touch items before purchasing them and may find it more acceptable to buy products from store-based retail formats (Sanguanpiyapan \& Jasper, 2010). 
Thus, consumers with the intention of giving a gift to someone choose shopping channels based on their familiarity with the levels of risk of the store. Lee and Kim (2009) propose that, in order to maximize the utility of the customer, the selection of an appropriate retail channel for the gift-shopping process may be related to the past personal purchase experiences. In this sense, one can assume that gift buyers have a utilitarian purchase motivation. In this study, the consumption motivation will be considered as the moderating variable for favorable or unfavorable responses when considering the atmosphere of the store, the consumer service, the creation of satisfaction, repurchase intention, and word of mouth about the store (see Figure 1).

H5: Consumers' motivational value (hedonic or utilitarian) moderates the relationship between the store and consumer response. Relationships considered are: a) the store atmosphere variables and satisfaction; b) the store atmosphere variables and consumer service; c) the consumer service and satisfaction; and d) satisfaction and the repurchase intention.

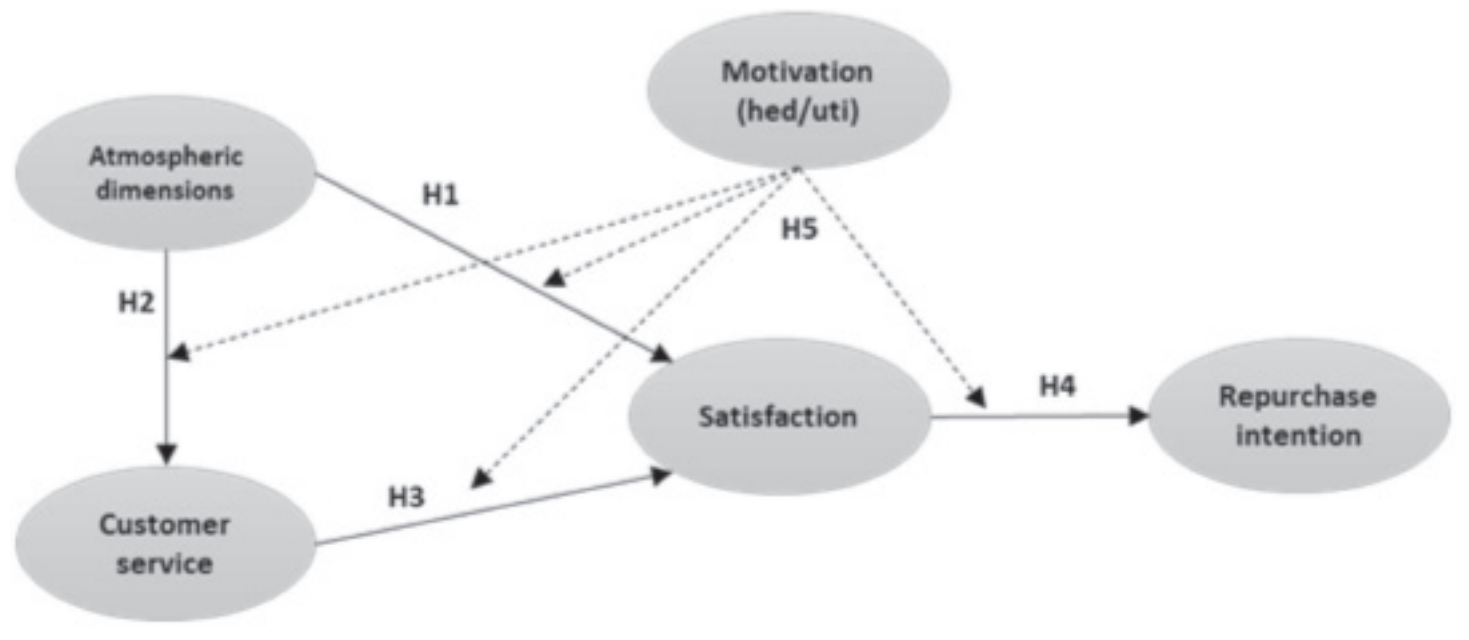

Figure 1. Structural model hypotheses.

Note. The atmosphere consists of seven constructs; the figure shows a simplified form of that variable. Dashed lines represent moderation of the model; model indicators are not shown in the figure.

\section{Methodology}

This study is quantitative and uses a mallintercept survey to collect data from consumers in the silver jewelry retail chain. The data analysis was conducted using the SmartPLS (partial least squares) software version 3 (Ringle, Wende, \& Becker, 2015). Structural equation modeling (PLS-SEM) was used to simultaneously examine the structural components measured and the proposed causal relationship based on a case of sample multivariate non-normality.

\section{I Data collection}

In the silver jewelry segment, the largest silver jewelry retailer in Brazil was chosen. This retailer is popular in Curitiba/PR and in the metropolitan region, where the questionnaires were collected. The population chosen for this study was defined as adult consumers who shop at the jewelry retailer. The mall-intercept survey of shoppers featured personal interviews involving a non-probabilistic sample.

A quasi-random sample was selected by intercepting consumers at strategic locations that 
were close to silver jewelry retail stores in different places in the city (Delgado-Ballester, HernandezEspallardo, \& Rodriguez-Orejuela, 2014). Two of the study's researchers who were there to collect the data approached different potential customers. The data collection was done during different times of the day and on different days of the week. People could refuse to answer the survey. The collection period was between September and November 2017.

The questionnaire was composed of two research filters: store awareness and if they had bought from the store. If both were positive, the respondents continued in the research, otherwise, it would end there. From that, the items measured the following variables: utilitarian and hedonic motivational value of the consumer (Voss, Spangenberg, \& Grohmann, 2003), assessment of the components of the store atmosphere (Hussain \& Ali, 2015), and the attendance of the retail chain (Brady et al., 2002), besides the variables of satisfaction and repurchase intention (Teixeira \& Hernandez, 2012). Finally, the questionnaire collected the respondent's demographic items. The questionnaire used has been included as an appendix to the article.

In total, 230 individuals answered the questionnaire, of which only 160 (69\%) were valid. We excluded the questionnaires in which respondents had no store awareness and did not buy from the silver jewelry store. The sample is mostly composed of women (77\%) with a mean age of 32 years; $63 \%$ were single and $25 \%$ married; $37 \%$ of the total sample indicated an incomplete level of high school education, 26\% had completed higher education, and 31\% were postgraduate level. The study considered current Brazilian economic classifications composed of the permanent income indicator variables (such as education, living conditions, access to public services, and possession of durable goods), as follows: $21 \%$ belong to class A, $22 \%$ to class B1, $41 \%$ to class $\mathrm{B} 2$, and $17 \%$ to class $\mathrm{C}(\mathrm{C} 1$ and $\mathrm{C} 2$ ). The most common frequency of purchases in the retail chain was once a year (29\%) and less than once a year (48\%). Most respondents (85\%) had shopped at the mall stores.

\subsection{Gift shops for silver jewelry}

Jewelry has long been embedded in human culture as a symbol of prosperity, wealth, and fortune. It is worn daily to show a wearer's social status. As a result, jewelry has become an essential part of people's daily use (Sanguanpiyapan \& Jasper, 2010), and is often characterized as a favorite, popular, and traditional gift item (Wolfinbarger, 1990).

Consumers usually choose to shop at a retail outlet because it offers five fundamental features: a good selection of merchandise, a variety of price ranges, products that fit their needs (size, style, etc.), convenient hours, and a convenient location (Sanguanpiyapan \& Jasper, 2010). Furthermore, consumers tend to match their functional and nonfunctional shopping motivations to retail attributes when establishing their jewelry shopping preferences for retail outlets. In general, jewelry shoppers are more influenced by functional motives (Sanguanpiyapan \& Jasper, 2010). Thus, utilitarian motives join the symbolic and simultaneously influence the decision to give jewelry as a gift (Ertimur \& Sandikci, 2005).

When considering silver jewelry retail stores that have a wider distribution, these stores can be classified as having non-exclusive products that are nearly specialty goods and customers that use purchase comparisons. According to Bucklin (1963), for this type of good, the consumer, prior to his/her need, has a preference map that indicates a willingness to spend the additional effort needed to buy the chosen item instead of buying a more affordable replacement. Thus, silver jewelry is not entirely a specialty good such as gold jewelry or precious stones, nor a convenience good, since its distribution is not very intense. With this, one can consider silver jewelry as somewhat of a specialty good under comparative shopping, since the consumer can compare the product and its desired attributes among other silver jewelry stores. 
Maybe for this reason, for Sanguanpiyapan and Jasper (2010), today's jewelry market is more complex due to increasing market fragmentation. Jewelry consumers are characterized and segmented by entirely different needs. For instance, there are male buyers versus female buyers, fine jewelry shoppers versus costume jewelry shoppers, and gift-purchasers versus self-purchasers. These segments overlap and intersect, requiring retailers to concentrate on specific segments rather than on the total market in response to the type of consumer. Therefore, the key to success for jewelry retailers is to understand the different personalities that make up the market and to present the kind of products, prices, and shopping experiences that the particular shopper desires. The distribution of choice rules consumers use for jewelry purchases is also likely to provide tactical or operational perspectives on retail competition.

To verify the strategic approach of the store atmosphere, analyze the different perceptions of store atmosphere, and evaluate the service quality based on consumer motivation, satisfaction, and intentional responses, this research meticulously studied these aspects in the silver jewelry retail segment. A retail chain of silver jewelry, the largest in Brazil, was chosen for the study. This retail chain has been present for more than 20 years in the market and attends public from classes $\mathrm{A}, \mathrm{B}$, and C, with 65 stores located in both malls and streets, distributed in the South and Southeast of the country.

According to data from the retail chain, as the size of the stores is generally small, the purchase time is important for the manager. The goal of the retailer is for purchases to be made quickly; consumers must buy, pay, and leave to avoid creating crowds and queues. This is justified by the low average ticket purchase, i.e. it is necessary to generate sales volume per consumer flow. Thus, although the company offers products for a more hedonic character, the purchase is treated in a transactional way. The strategy used to create a buying experience is carried out by the sales team, with training and great care in the appearance of the salespeople.

\section{Results}

For the data analysis, confirmatory factor analysis (CFA) was first carried out to verify the contribution of each scale's item with its respective latent construct and to confirm the proposed relationships. Two items of the Customer Service variable and one item of the Music variable were excluded because they had a load factor below 0.6. With PLS-SEM, to confirm the CFA hypotheses for the measurement model the only metrics applied are reliability, convergent validity, and discriminant validity (Hair, Hult, Ringle, $\&$ Sarstedt et al., 2016). Among the results of this first examination were the indicator's load of each item, Cronbach's $\alpha$, construct reliability, and convergent validities, obtained by the average variance extracted (AVE). The blindfolding procedure was carried out to calculate the relevance or predictive validity $\left(\mathrm{Q}^{2}\right)$, and the size of the effect $\left(f^{2}\right)$, which evaluates how much each construct is useful for a model adjustment (Ringle et al., 2015). Table 1 shows the results. 
Table 1

Results of reflective measurement model

\begin{tabular}{|c|c|c|c|c|c|c|c|}
\hline Dimension & $\begin{array}{c}\mathrm{R} \\
\text { squared }\end{array}$ & $\begin{array}{c}\text { Adjusted R } \\
\text { Squared }\end{array}$ & $\begin{array}{l}\text { Composite } \\
\text { Reliability }\end{array}$ & AVE & Cronbach's $\alpha$ & $\operatorname{COM}\left(\mathbf{f}^{2}\right)$ & $\operatorname{RED}\left(\mathbf{Q}^{2}\right)$ \\
\hline Consumer Service & 0.273 & 0.239 & 0.945 & 0.683 & 0.946 & 0.613 & 0.143 \\
\hline Satisfaction & 0.485 & 0.458 & 0.897 & 0.686 & 0.894 & 0.56 & 0.278 \\
\hline Repurchase Intention & 0.628 & 0.626 & 0.839 & 0.642 & 0.839 & 0.462 & 0.342 \\
\hline \multirow{7}{*}{ 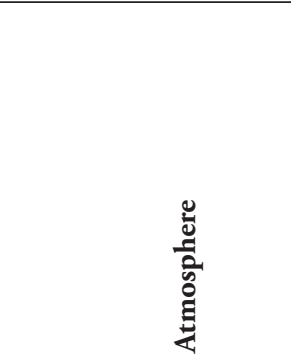 } & Scent & & 0.949 & 0.862 & 0.949 & 0.689 & _- \\
\hline & Color & & 0.933 & 0.824 & 0.933 & 0.656 & - \\
\hline & \multicolumn{2}{|c|}{ Display/layout } & 0.886 & 0.608 & 0.884 & 0.506 & - \\
\hline & \multicolumn{2}{|l|}{ Lighting } & 0.939 & 0.721 & 0.940 & 0.637 & - \\
\hline & \multicolumn{2}{|c|}{ Cleanliness } & 0.849 & 0.653 & 0.850 & 0.477 & - \\
\hline & \multicolumn{2}{|l|}{ Music } & 0.899 & 0.640 & 0.900 & 0.538 & - \\
\hline & \multicolumn{2}{|c|}{ Temperature } & 0.791 & 0.581 & 0.746 & 0.384 & - \\
\hline
\end{tabular}

Note. Store atmosphere consists of seven predictors, which are scent, cleanliness, music, lighting, temperature, color, and display/layout of the outlet. "Effect of store atmosphere on consumer purchase intention", by R. Hussain \& M. Ali (2015).

The loads presented indexes above 0.6. In addition, the Cronbach's $\alpha$, the AVE, and the reliability of the construct indicate a good convergence and guarantee the model's internal validity. The results of the blindfolding test imply that all latent variables have a broad effect for the research model; also, the $\mathrm{Q}^{2}$ values for all endogenous constructs show the model's predictive relevance.

The $\mathrm{R}^{2}$ resulting from the constructs of the model includes $27 \%$ for the 'consumer service' variable, $48 \%$ for 'satisfaction,' and $62 \%$ for the 'repurchase intention' variable. These values help to determine that the latent predictive variables have a substantial and significant effect on the endogenous variables. This value emphasizes that these aspects in the store environment cannot go ignored in the retailer's strategies, and also that satisfied consumers who recommend the store have a great chance of buying again.

With estimates of the correlations of the model constructs, we made the analysis of discriminant validity. The Fornell-Larcker criterion compares the square root of the average variance extracted (AVE) with the correlation of latent constructs (Hair et al., 2016). A latent construct should better explain the variance of its own indicator rather than the variance of other latent constructs. Therefore, the square root of each construct's AVE should have a greater value than the correlations with other latent constructs. This is accomplished by the results (Table 2). 
Table 2

Discriminant validity analysis of constructs with PLS

\begin{tabular}{|c|c|c|c|c|c|c|c|c|c|c|}
\hline & \multicolumn{10}{|c|}{ Correlations matrix - Fornell Larcker criterion } \\
\hline & Cleanliness & Color & Con.Service & Display & Lighting & Music & Repurchase & Satisfaction & Scent & Temp. \\
\hline Cleanliness & 0.808 & & & & & & & & & \\
\hline Color & 0.434 & 0.908 & & & & & & & & \\
\hline Con.Service & 0.215 & 0.396 & 0.827 & & & & & & & \\
\hline Display & 0.465 & 0.781 & 0.493 & 0.780 & & & & & & \\
\hline Lighting & 0.563 & 0.720 & 0.315 & 0.768 & 0.849 & & & & & \\
\hline Music & 0.503 & 0.548 & 0.123 & 0.456 & 0.575 & 0.800 & & & & \\
\hline Repurchase & 0.381 & 0.459 & 0.529 & 0.589 & 0.503 & 0.294 & 0.801 & & & \\
\hline Satisfaction & 0.409 & 0.446 & 0.513 & 0.620 & 0.545 & 0.330 & 0.793 & 0.828 & & \\
\hline Scent & 0.608 & 0.476 & 0.175 & 0.360 & 0.454 & 0.525 & 0.345 & 0.282 & 0.928 & \\
\hline Temperature & 0.438 & 0.489 & 0.225 & 0.620 & 0.617 & 0.502 & 0.284 & 0.389 & 0.488 & 0.762 \\
\hline
\end{tabular}

The bootstrapping technique was performed for 5,000 subsamples, which provides the standard error of an estimated coefficient, creates the ability to determine the empirical t-value (Hair et al., 2016), and evaluates the significance of the path coefficients (p-value) (see Figure 2).

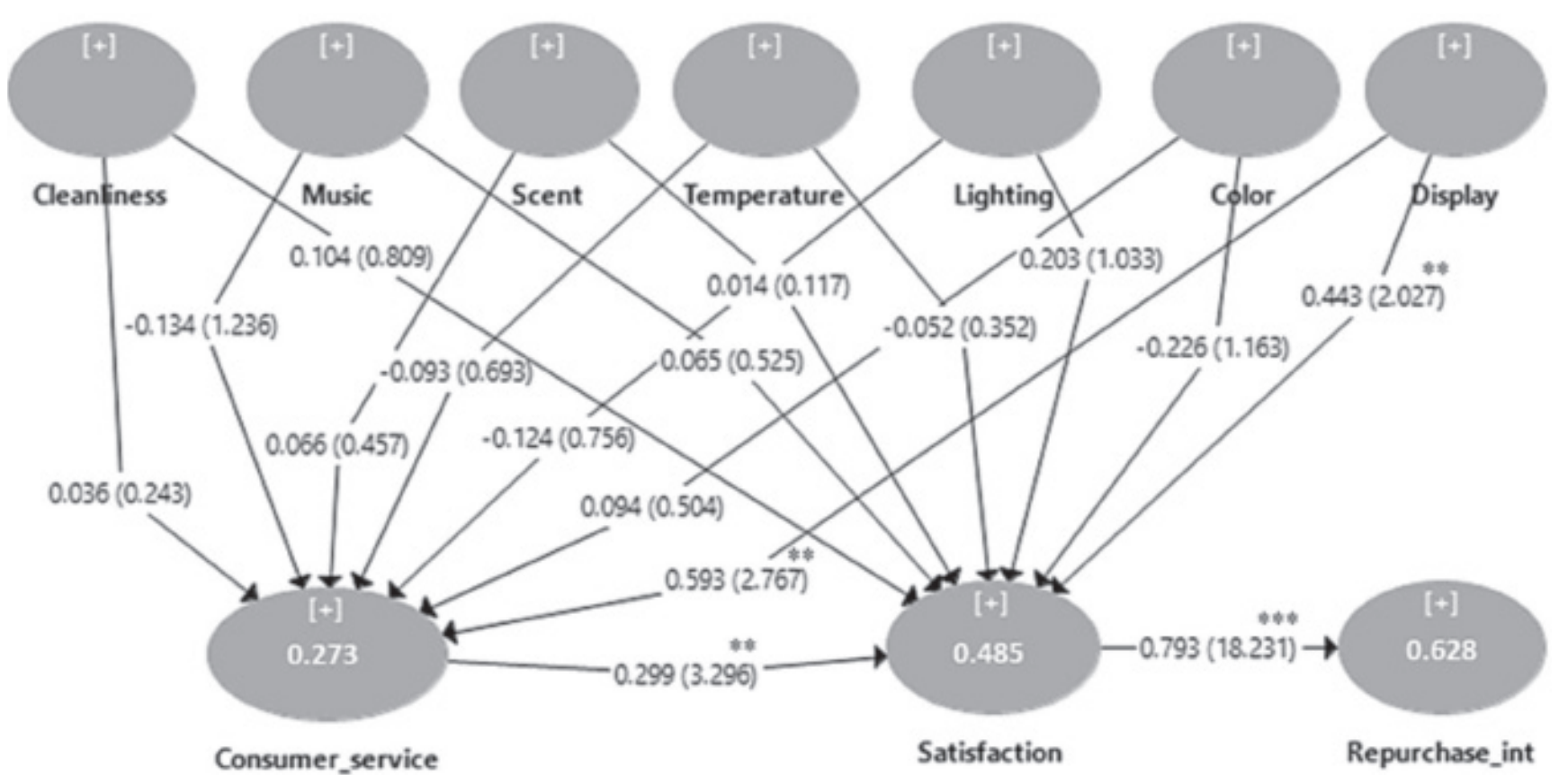

Figure 2. Structural model results: path coefficients, t-values, p-values.

Note. SMSR $=0.062$; $\mathrm{t}$-value in parenthesis; R squared within constructs; ${ }^{* * *} \mathrm{p}<0.001 ;{ }^{* *} \mathrm{p}<0.05 ;{ }^{*} \mathrm{p}<0.10$; model indicators are not shown in the figure. 
The approximate model fit criterion implemented for the PLS path modeling is the standardized root mean square residual (SRMR). The SRMR is the square root of the sum of the squared differences between the model-implied and the empirical correlation matrix. A cut-off value of 0.08 appears to be more adequate for PLS path models (Henseler, Hubona, \& Ray, 2016), so the SMRS in this model (0.062) was considered appropriate. As a result, it can be said that the correlations and regression coefficients are significant. Just as the paths between the reflective constructs (and between the latent variables and the constructs) are significant, the structural model can be considered adjusted. High $\mathrm{R}^{2}$ values also indicate that the values of the construct can be well predicted via the PLS path model.

As a result, it should be noted that the store's display/layout positively and significantly affects customer service $(\mathrm{t}$-value $=2.767$, $\mathrm{p}$-value
$=0.005)$ and satisfaction $(\mathrm{t}$-value $=2.032$, $\mathrm{p}$-value $=0.042$ ). This means that retailers need to generate creative and attractive environments with high product availability and visibility, which encourages consumers to stay in the store, look more closely at products, and select products. As a consequence, the store's display/ layout positively affects customer service and perception of store satisfaction. Customer service positively affects customer satisfaction ( $\mathrm{t}$-value $=$ 3.296 , $\mathrm{p}$-value $=0.001)$. Thus, employees who are courteous, polite, and respectful and who provide a service reliably, consistently, and in a trustworthy way, are key to the positive perception of store consumers, favoring decision making and satisfaction. Satisfaction positively affects the repurchase intention for the store's products $(\mathrm{t}$-value $=18.231, \mathrm{p}$-value $<0.001)$.

The structural model test can be observed in the hypothesis results (Table 3):

Table 3

Summary of the research hypotheses based on the structural model

\begin{tabular}{|c|c|c|c|c|}
\hline Hypothesis & Condition & t values & $p$ values & Hypothesis test \\
\hline $\mathrm{H} 1 \mathrm{a}$ & CLEA $\rightarrow$ SAT & 0.822 & 0.411 & Rejected \\
\hline $\mathrm{H} 1 \mathrm{~b}$ & MUS $\rightarrow$ SAT & 0.523 & 0.601 & Rejected \\
\hline $\mathrm{H} 1 \mathrm{c}$ & $\mathrm{TEMP} \rightarrow \mathrm{SAT}$ & 0.345 & 0.730 & Rejected \\
\hline $\mathrm{H} 1 \mathrm{~d}$ & $\mathrm{COL} \rightarrow \mathrm{SAT}$ & 1.166 & 0.244 & Rejected \\
\hline H1e & $\mathrm{LIGH} \rightarrow$ SAT & 1.039 & 0.299 & Rejected \\
\hline H1f & $\mathrm{DIS} \rightarrow \mathrm{SAT}$ & 2.032 & 0.042 & Confirmed \\
\hline H1g & $\mathrm{SCE} \rightarrow \mathrm{SAT}$ & 0.119 & 0.905 & Rejected \\
\hline $\mathrm{H} 2 \mathrm{a}$ & CLEA $\rightarrow$ SER & 0.247 & 0.805 & Rejected \\
\hline $\mathrm{H} 2 \mathrm{~b}$ & MUS $\rightarrow$ SER & 1.233 & 0.218 & Rejected \\
\hline $\mathrm{H} 2 \mathrm{c}$ & TEMP $\rightarrow$ SER & 0.684 & 0.494 & Rejected \\
\hline $\mathrm{H} 2 \mathrm{~d}$ & $\mathrm{COL} \rightarrow \mathrm{SER}$ & 0.518 & 0.605 & Rejected \\
\hline $\mathrm{H} 2 \mathrm{e}$ & $\mathrm{LIGH} \rightarrow$ SER & 0.751 & 0.453 & Rejected \\
\hline H2f & $\mathrm{DIS} \rightarrow \mathrm{SER}$ & 2.800 & 0.005 & Confirmed \\
\hline $\mathrm{H} 2 \mathrm{~g}$ & $\mathrm{SCE} \rightarrow \mathrm{SER}$ & 0.464 & 0.643 & Rejected \\
\hline H3 & SER $\rightarrow$ SAT & 3.293 & 0.001 & Confirmed \\
\hline $\mathrm{H} 4$ & $\mathrm{SAT} \rightarrow \mathrm{REP}$ & 17.859 & $<0.001$ & Confirmed \\
\hline
\end{tabular}

Note. Student t-test values obtained through the SmartPLS 3.0 bootstrapping module (5000). CLEA: Cleanliness; MUS: Music; TEMP: Temperature; COL: Color; LIGH: Lighting; DIS: Display; SCE: Scent; SAT: satisfaction; SER: consumer service quality; REP: repurchase intention. 
Based on the results of the proposed structural model, in opposition to much of the store atmosphere literature, the hypotheses related to the components of the atmosphere (cleanliness, music, temperature, lighting, color, and scent) were not corroborated, which means that it has no significant impact on customer service and consumer satisfaction. Only the store's display/ layout has a significant impact on satisfaction (H1f: $\mathrm{t}=2.032 ; \mathrm{p}=0.042)$ and consumer service (H2f: $\mathrm{t}=2.800 ; \mathrm{p}=0.005)$, demonstrating that the way products are exposed helps the seller in their work, it positively favors products being chosen, and the time the customer remains in the store, leading to satisfaction. In addition, the consumer service influences consumer satisfaction $(\mathrm{H} 3: \mathrm{t}=3.293 ; \mathrm{p}=0.001)$. It should be emphasized that satisfaction positively impacts repurchase intention ( $\mathrm{H} 4: \mathrm{t}=17859 ; \mathrm{p}<0.001)$, in the sense that buying at the store means a good choice and makes the person happy. This result may be because the silver jewelry store presents a more utilitarian approach and most of the respondents present a utilitarian motivation.

To verify if the results differ based on consumers' motivational value, the research data were subjected to partial least squares multi-group analysis (PLS-MGA), which divided the sample into hedonic $(n=57)$ and utilitarian $(n=103)$. This analysis allows a comparison of path coefficients across two data groups (Hair et al., 2016). The existence of sample heterogeneity was analyzed by the Welch-Satterthwait test (Table 4).

Table 4

Multi-group analysis by Welch-Satterthwait test

\begin{tabular}{|c|c|c|c|c|c|c|}
\hline Hypothesis & Condition & $\begin{array}{l}\text { t-Values } \\
\text { (Hedonic) }\end{array}$ & $\begin{array}{c}\text { t-Values } \\
\text { (Utilitarian) }\end{array}$ & $\begin{array}{c}\text { Path Coefficients-diff } \\
\text { (HedvsUti) }\end{array}$ & $\begin{array}{c}\text { t-Value } \\
\text { (HedvsUti) }\end{array}$ & $\begin{array}{c}\text { p-Value } \\
\text { (HedvsUti) }\end{array}$ \\
\hline $\mathrm{H} 1 \mathrm{a}$ & CLEA $\rightarrow$ SAT & 1.220 & 0.777 & 0.114 & 0.628 & 0.531 \\
\hline H1b & MUS $\rightarrow$ SAT & 1.481 & 2.209 & 0.497 & 2.508 & $0.013^{* *}$ \\
\hline $\mathrm{H} 1 \mathrm{c}$ & TEMP $\rightarrow$ SAT & 1.423 & 0.937 & 0.309 & 1.551 & 0.123 \\
\hline H1d & $\mathrm{COL} \rightarrow \mathrm{SAT}$ & 0.466 & 2.066 & 0.378 & 1.636 & 0.104 \\
\hline H1e & LIGH $\rightarrow$ SAT & 0.006 & 1.027 & 0.193 & 0.666 & 0.507 \\
\hline H1f & $\mathrm{DIS} \rightarrow \mathrm{SAT}$ & 2.013 & 2.690 & 0.040 & 0.175 & 0.862 \\
\hline $\mathrm{H} 1 \mathrm{~g}$ & $\mathrm{SCE} \rightarrow \mathrm{SAT}$ & 0.139 & 0.583 & 0.079 & 0.442 & 0.659 \\
\hline $\mathrm{H} 2 \mathrm{a}$ & CLEA $\rightarrow$ SER & 1.106 & 0.510 & 0.280 & 1.192 & 0.235 \\
\hline $\mathrm{H} 2 \mathrm{~b}$ & MUS $\rightarrow$ SER & 0.184 & 1.678 & 0.235 & 1.116 & 0.266 \\
\hline $\mathrm{H} 2 \mathrm{c}$ & TEMP $\rightarrow$ SER & 1.037 & 0.384 & 0.208 & 0.855 & 0.394 \\
\hline $\mathrm{H} 2 \mathrm{~d}$ & $\mathrm{COL} \rightarrow \mathrm{SER}$ & 0.010 & 2.572 & 0.402 & 1.641 & 0.103 \\
\hline $\mathrm{H} 2 \mathrm{e}$ & $\mathrm{LIGH} \rightarrow$ SER & 0.901 & 0.249 & 0.194 & 0.730 & 0.466 \\
\hline $\mathrm{H} 2 \mathrm{f}$ & DIS $\rightarrow$ SER & 5.114 & 0.552 & 0.635 & 2.459 & $0.014^{* *}$ \\
\hline $\mathrm{H} 2 \mathrm{~g}$ & $\mathrm{SCE} \rightarrow \mathrm{SER}$ & 0.456 & 0.118 & 0.095 & 0.410 & 0.683 \\
\hline $\mathrm{H} 3$ & SER $\rightarrow$ SAT & 2.437 & 3.382 & 0.065 & 0.424 & 0.672 \\
\hline H4 & $\mathrm{SAT} \rightarrow \mathrm{REP}$ & 17.496 & 13.390 & 0.162 & 2.196 & $0.029^{* *}$ \\
\hline
\end{tabular}

Note. ${ }^{* * *} \mathrm{p}<0.001 ;{ }^{* *} \mathrm{p}<0.05 ;{ }^{*} \mathrm{p}<0.10$. Research data generated by SmartPLS 3.

Based on the data from the multi-group analysis, it can be seen that the difference between the hedonic and utilitarian consumers arises only for three relationships studied: between music and satisfaction ( $\mathrm{p}=0.013)$, display and consumer service $(\mathrm{p}=0.014)$, and satisfaction and repurchase intention $(p=0.029)$. The results indicate that, although the literature addresses motivation as 
an important factor in the perception of the atmosphere and the retail consumer service, there was a significant difference only for twoatmosphere components and for the consumer response variables.

For utilitarian consumers, the store's background music positively affects the perception of satisfaction $(\mathrm{H} 1 \mathrm{~b}$ : $\mathrm{t}$-value $=2.209$, $\mathrm{p}$-value $=$ $0.027)$. This means that music creates a relaxing and comfortable environment that motivates consumers to stay longer in the store. Also, the background music can positively affect well-being and convenience, favoring the purchase time. Another component of the store atmosphere that showed a significant result was the display/ layout, which had an impact on consumer service for hedonic consumers (H2f: $\mathrm{t}$-value $=5.114$, $\mathrm{p}$-value $=0.000)$. Thus, creative and attractive environments with high visibility and product availability affect the consumers' permanence in the store and the perception of the customer service. These factors contribute to a more pleasant purchase.
From the comparative results between the two consumer motivational values, it can be observed that hedonic consumers consider store satisfaction as a repurchase intention indicator $(\mathrm{t}$-value $=17.496, \mathrm{p}$-value $<0.001)$. Thus, consumer goals provide a general approach to understanding influences on buying behavior and experience, which affects satisfaction with the purchase and with the retailer. Among the relationships of the structural model, the relationship of satisfaction generating repurchase intention was not significant for utilitarian consumers.

\section{Discussion}

Considering that about $64 \%$ of the survey respondents (brand consumers) classify themselves as utilitarian buyers, the retailer's strategy presents some coherence with the public profile. However, is this enough to generate satisfaction and repurchase intention? The research gives some indications of answers to these questions, as can be seen in Table 5 .

Table 5

\section{Summary of the research hypotheses based on the motivational value of the consumers as a moderator}

\begin{tabular}{|c|c|c|c|}
\hline Hypothesis & & Moderator & Hypothesis test \\
\hline \multirow{7}{*}{$\mathrm{H} 7 \mathrm{a}$} & CLEA $\rightarrow$ SAT & \multirow{15}{*}{$\begin{array}{c}\text { MOT } \\
\text { (Hed vs Uti) }\end{array}$} & Rejected \\
\hline & MUS $\rightarrow$ SAT & & Confirmed \\
\hline & $\mathrm{TEMP} \rightarrow$ SAT & & Rejected \\
\hline & $\mathrm{COL} \rightarrow \mathrm{SAT}$ & & Rejected \\
\hline & $\mathrm{LIGH} \rightarrow$ SAT & & Rejected \\
\hline & DIS $\rightarrow$ SAT & & Rejected \\
\hline & $\mathrm{SCE} \rightarrow \mathrm{SAT}$ & & Rejected \\
\hline \multirow{7}{*}{$\mathrm{H} 7 \mathrm{~b}$} & CLEA $\rightarrow$ SER & & Rejected \\
\hline & MUS $\rightarrow$ SER & & Rejected \\
\hline & TEMP $\rightarrow$ SER & & Rejected \\
\hline & $\mathrm{COL} \rightarrow \mathrm{SER}$ & & Rejected \\
\hline & LIGH $\rightarrow$ SER & & Rejected \\
\hline & $\mathrm{DIS} \rightarrow$ SER & & Confirmed \\
\hline & $\mathrm{SCE} \rightarrow \mathrm{SER}$ & & Rejected \\
\hline $\mathrm{H} 7 \mathrm{c}$ & $\mathrm{SER} \rightarrow \mathrm{SAT}$ & & Rejected \\
\hline $\mathrm{H} 7 \mathrm{~d}$ & $\mathrm{SAT} \rightarrow \mathrm{REP}$ & & Confirmed \\
\hline
\end{tabular}

Note. CLEA: Cleanliness; MUS: Music; TEMP: Temperature; COL: Color; LIGH: Lighting; DIS: Display; SCE: Scent; SAT: satisfaction; SER: consumer service quality; REP: repurchase intention; MOT: consumer motivation. 
Considering motivation as a moderator variable, it was expected that all findings would indicate that the effects of the store variables vary depending on the goals that the customers entertain on entering the retail environment. However, there was only statistical significance found for H7a (Music), H7b (Display), and $\mathrm{H} 7 \mathrm{~d}$. One possible explanation is that not all the variables that make up the store atmosphere were addressed. Another issue is that as most respondents in the study considered the silver jewelry stores located in shopping centers (85\% of the answers), it is emphasized that shopping centers do not only have an offer based on the variety and quality of the articles and services delivered but also suggest images or perceptions of status from the brands marketed in these spaces (Ortegón-Cortázar \& Royo-Vela, 2017).

Music was shown to positively affect the satisfaction of utility consumers, demonstrating that environments that match the background music with the store favor product purchases and personal well-being. This corroborates the studies of Chebat et al. (2001), Hussain and Ali (2015), and Yalch and Spangenberg (2000). Chebat et al. (2001) demonstrate that music affects attitudes through the cognitive process. The background music increases sales and improves positive attitudes about the store (Chebat et al., 2001), and affects the length of stay and customer purchases (Yalch \& Spangenberg, 2000). Since consumers are focused on the task of buying, they seek to plan in advance which stores they will visit and tend to minimize the time they spend in store (Büttner et al., 2013). Music works to benefit this buying motivation, facilitating the "hit," thus explaining the importance of adequate background music in the store.

The store display/layout positively affected the perception of customer service for hedonic consumers. These results corroborate the study by Ballantine et al. (2010), in which facilitating stimuli such as product displays and layout positively affect the hedonic experience of individuals, having a strong impact on purchase intention and the customer's perception of the store. This element of store atmosphere assists the work of customer service. In this sense, the products at the point of sale should be displayed in a way that attracts consumers. Store displays that favor a breadth of display and selection of products are important sources of consumer information, and essential for gift buyers (Laroche et al., 2000a). These factors should be well explored when building the atmosphere of a gift shop (Hussain \& Ali, 2015).

Regarding the non-significance of the other store atmosphere elements, the results corroborate Van Rompay et al. (2012), who indicate that, for task-oriented buyers, environment variables that do not have a direct impact on their behavior or are less influential, thereby suggesting that task-oriented shoppers are not positively affected by nonfunctional aspects of store design. This coincides with Ladeira et al. (2016), in which the relationship between utility value and satisfaction was not significant. This result was also noticed for hedonic consumers, since hypotheses $\mathrm{H} 7 \mathrm{a}$ and $\mathrm{H} 7 \mathrm{~b}$ (except for display), which tested the moderating effect of consumer motivation on the store atmosphere variables' relationship with consumer satisfaction and service was not significant. For Muhammad et al. (2014), the ambient factors do not significantly affect the shoppers' hedonic experience and it can be presumed that this may be because the environment contains non-visual elements, and shoppers may not notice it.

Hypothesis $\mathrm{H} 7 \mathrm{c}$, which affirmed that the motivational value of the consumers would moderate the influence of the service on satisfaction, was also not significant. In other words, customer service did not generate a difference in the satisfaction of the consumers when considering the hedonic or utilitarian motivations. The research confirmed hypothesis $\mathrm{H} 7 \mathrm{~d}$; that is, the consumer's motivational value moderates the influence of satisfaction on repurchase intention, being significant for the hedonic value consumers. 
Hedonic consumers tend to seek pleasant shopping experiences during the period they remain in the store. They seek a certain satisfaction during their purchases. Therefore, satisfaction or dissatisfaction is observed as a consequence of the intention of choosing to repurchase or not in the store. Given this behavior, $\mathrm{H} 7 \mathrm{~d}$ can justifiably be confirmed for the hedonic motivational value, to the detriment of the utility value.

\section{Theoretical and Managerial Contributions}

The results confirm that hedonic consumers and utilitarian consumers differ in cognitive procedures that are activated while shopping, at least in regard to repurchase intention. As theoretical contributions, this study endorses the theory of consumer motivation, indicating that different cognitive processes are activated during retail purchases. This fact reinforces the importance of studies in services and retail on the store atmosphere and customer service. In particular, the study contributes to the understanding of the gift store atmosphere for the silver jewelry sector. In general, there are few studies that address this segment.

Motivation is an important aspect of the retail shopping process and behavioral responses. Furthermore, one managerial recommendation is that it is necessary to understand the needs and desires of consumers and their purchase motivations so that marketing managers can offer consumers the best service (Alavi et al., 2015) according to their orientations and decisions in retail. Knowing which motivations are active in a situation, and how activation varies across situations, provides valuable knowledge about what information consumers may pay attention to, what products they prefer, and what marketing strategies may be most effective (Barbopoulos \& Johansson, 2017).

Regarding the store atmosphere, for managers, more attention should be given to background music, since even utilitarian consumers feel more satisfied in environments with congruent music. Thus, it is important to know that musical style generates more comfort and well-being and encourages permanence in the store. In addition, focus should be given to the product display in the store and to a creative and attractive layout, which favors both selection and purchase of products and the work of sellers. A good display/layout in the store makes consumers pay more attention to the products and feel more at ease.

In terms of management, retailers can increase consumer satisfaction by exploring the store atmosphere (tangible and intangible store attributes) and focusing on hedonic motivational value (Ladeira et al., 2016), to directly impact customer satisfaction (Jones, 1999). The fact that the study deals with a hedonic product in a utilitarian environment with a focus on tangible attributes ends up diluting the hedonic perspective of this category of products. Perhaps this is one reason most consumers were found to have a utilitarian rather than hedonic motivation.

\section{Final Considerations}

More and more retailers are realizing that the growth and profitability of their businesses depend on relatively small factors, but ones that make a big difference in consumer satisfaction and loyalty. Some examples are the possibility of easy consumer-company interaction, alignment of communication, offering multiple purchase channels, and sensitivity to the needs of consumers and their feedback (Grewal et al., 2009). In this sense, the store atmosphere can be exploited in several ways to improve the consumers' satisfaction and repurchase intention. This study verified how consumers perceive the retail store atmosphere, starting by identifying the motivational aspect, and thus contributing to understanding hedonic and utilitarian consumer motivations in the retail environment.

The study demonstrates, via the elements of the store atmosphere, that music affects attitudes through the cognitive process (Chebat et al., 2001), favoring store satisfaction for utilitarian 
consumers. The background music improves positive attitudes about the store, and affects the length of stay, comfort, and customer purchases (Chebat et al., 2001; Yalch \& Spangenberg, 2000). Importantly, as utility consumers seek efficiency when purchasing, aspects such as purchase time are critical. Also, music affects the perception of service time, facilitating a fast service with a focus on specialized benefits for utilitarian consumers (Bäckström \& Johansson, 2006).

For hedonic consumers, the store display/ layout positively affected the customer's perception regarding the customer service, because they are important sources of consumer information and positively affect the hedonic experience of individuals (Ballantine et al., 2010). So, this store atmosphere element assists customer service. Thus, the product display at the point of sale and the store's layout should be arranged in a way that attracts consumers and favors product selection, which is essential for gift buyers (Laroche et al., 2000a). Therefore, these factors should be well explored in the atmosphere strategies of gift shops.

On the other hand, in the relationship between satisfaction and repurchase intention, consumers with a hedonic motivation showed a significant result, whereas for utilitarian consumers this relationship was not significant. This may indicate that for consumers with a hedonic motivation, being satisfied with the atmosphere and/or the care received led them to have repurchase intention. This result confirms the study by Ballantine et al. (2010), which states that motivation tends to affect the evaluation of atmosphere. In addition, when hedonic consumers give priority to the buying experience what matters is a personal evaluation.

Among the limitations of the study, there is a high percentage $(85 \%)$ of consumers from shopping mall stores. Another limitation is the use of the reduced sample and the low frequency of purchase in the retail chain. Future research could explore what other different factors make up the store's atmosphere, for different retail stores, and see how those specific features affect consumer satisfaction. Another potential area for future exploration would be to compare the model for services and to understand if consumer motivation has a greater influence in this sector. In addition to exploring consumer motivation, future research could also address the level of consumer involvement with the product. A final suggestion would be to adapt the model to the online retail environment in e-commerce stores.

\section{References}

Alavi, S. A., Rezaei, S., Valaei, N., \& Wan Ismail, W. K. (2015). Examining shopping mall consumer decision-making styles, satisfaction and purchase intention. The International Review of Retail, Distribution and Consumer Research, 26(3), 272-303.

Babin, B. J., Darden, W. R., \& Griffin, M. (1994). Work and/or fun: Measuring hedonic and utilitarian shopping value. Journal of consumer research, 20(4), 644-656.

Bäckström, K., \& Johansson, U. (2006). Creating and consuming experiences in retail store environments: Comparing retailer and consumer perspectives. Journal of Retailing and Consumer Services, 13(6), 417-430. doi: 10.1016/j.jretconser.2006.02.005

Baker, J., Grewal, D., \& Parasuraman, A. (1994). The influence of store environment on quality inferences and store image. Journal of the academy of marketing science, 22(4), 328-339.

Ballantine, P. W., Jack, R., \& Parsons, A. G. (2010). Atmospheric cues and their effect on the hedonic retail experience. International Journal of Retail \& Distribution Management, 38(8), 641653. doi: 10.1108/09590551011057453

Barbopoulos, I., \& Johansson, L.-O. (2017). The consumer motivation scale: Development of a multi-dimensional and context-sensitive measure of consumption goals. Journal of Business Research, 76, 118-126. doi: 10.1016/j.jbusres.2017.03.012 
Becerril-Arreola, R., Zhou, C., Srinivasan, R., \& Seldin, D. (2017). Service satisfactionmarket share relationships in partnered hybrid offerings. Journal of Marketing, 81(5), 86-103. doi:10.1509/jm.15.0537

Blackwell, R. D., Miniard, P. W., \& Engel, J. F. (2005). Comportamento do consumidor. São Paulo: Pioneira Thomson Learning.

Brady, M. K., Cronin, J. J., Jr., \& Brand, R. R. (2002). Performance-only measurement of service quality: A replication and extension. Journal of business research, 55(1), 17-31.

Bitner, M. J. (1992). Servicescapes: The impact of physical surroundings on customers and employees. The Journal of Marketing, 57-71. doi: $10.2307 / 1252042$

Bucklin, L. P. (1963). Retail strategy and the classification of consumer goods. The Journal of Marketing, 27(1), 50-55. doi: 10.2307/1248582

Büttner, O. B., Florack, A., \& Göritz, A. S. (2013). Shopping orientation and mindsets: How motivation influences consumer information processing during shopping. Psychology \& Marketing, 30(9), 779-793. doi: 10.1002/ mar.20645

Chebat, J. C., Chebat, C. G., \& Vaillant, D. (2001). Environmental background music and in-store selling. Journal of Business Research, 54(2), 115-123. doi: 10.1016/S0148-2963(99)00089-2.

Cronin, J. J., Brady, M. K., \& Hult, G. T. M. (2000). Assessing the effects of quality, value, and customer satisfaction on consumer behavioral intentions in service environments. Journal of Retailing, 76(2), 193-218. doi: 10.1016/S00224359(00)00028-2

Dabholkar, P. A., Thorpe, D. I., \& Rentz, J. O. (1996). A measure of service quality for retail stores: Scale development and validation. Journal of the Academy of Marketing Science, 24(3).
Delgado-Ballester, E., Hernandez-Espallardo, M., \& Rodriguez-Orejuela, A. (2014). Store image influences in consumers' perceptions of store brands: The moderating role of value consciousness. European Journal of Marketing, 48(9/10), 1850-1869.

Doucé, L., \& Janssens, W. (2013). The presence of a pleasant ambient scent in a fashion store: The moderating role of shopping motivation and affect intensity. Environment and Behavior, 45, 215-238. doi: 10.1177/0013916511410421

Ertimur, B., \& Sandikci, O. (2005). Giving gold jewelry and coins as gifts: The interplay of utilitarianism and symbolism. Advances in Consumer Research, 32, 322-327.

Grewal, D., Levy, M., \& Kumar, V. (2009). Customer experience management in retailing: An organizing framework. Journal of Retailing, 85(1), 1-14. doi: 10.1016/j.jretai.2009.01.001

Haas, A., \& Kenning, P. (2014). Utilitarian and hedonic motivators of shoppers' decision to consult with salespeople. Journal of Retailing, 90(3), 428441. doi: 10.1016/j.jretai.2014.05.003

Hair, J. F., Jr., Hult, G. T. M., Ringle, C., \& Sarstedt, M. (2016). A primer on partial least squares structural equation modeling (PLS-SEM) (2nd ed.). California: Sage, Thousand Oaks.

Henseler, J., Hubona, G., \& Ray, P. A. (2016). Using PLS path modeling in new technology research: Updated guidelines. Industrial management \& data systems, 116(1), 2-20.

Huang, L. C. (2007). Behavioral differences in prepurchase processes between purchasers of flowers for self use and for gift use. HortTechnology, 17(2), 183-190.

Hussain, R., \& Ali, M. (2015). Effect of store atmosphere on consumer purchase intention. International Journal of Marketing Studies, 7(2). doi: 10.5539/ijms.v7n2p35 
Jones, M. A. (1999). Entertaining shopping experiences: An exploratory investigation. Journal of Retailing and Consumer Services, 6(3), 129-139. doi: 10.1016/S0969-6989(98)00028-9

Kotler, P., Ayes, T., \& Bloom, P. N. (2002). Marketing de serviços profissionais: Estratégias inovadoras para impulsionar sua atividade, sua imagem e seus lucros. São Paulo: Manole.

Ladeira, W. J., Nique, W. M., Pinto, D. C., \& Borges, A. (2016). Running for pleasure or performance? How store attributes and hedonic product value influence consumer satisfaction. The International Review of Retail, Distribution and Consumer Research, 26(5), 502-520. doi: 10.1080/09593969.2016.1182934

Laroche, M., Saad, G., Kim, C., \& Browne, E. (2000a). A cross-cultural study of in-store information search strategies for a Christmas gift. Journal of Business Research, 49(2), 113-126.

Laroche, M., Saad, G., Browne, E., Cleveland, M., \& Kim, C. (2000b). Determinants of instore information search strategies pertaining to a Christmas gift purchase. Canadian Journal of Administrative Sciences, 17(1), 1-19. doi: 10.1111/j.1936-4490.2000.tb00203.x

Lee, H. H., \& Kim, J. (2009). Gift shopping behavior in a multichannel retail environment: The role of personal purchase experiences. International Journal of Retail \& Distribution Management, 37(5), 420-439. doi: 10.1108/09590550910954919

Lovelock, C. H., \& Wirtz, J. (2011). Marketing de serviços: Pessoas, tecnologia e resultados. São Paulo: Pearson Prentice Hall.

Muhammad, N. S., Musa, R., \& Ali, N. S. (2014). Unleashing the effect of store atmospherics on hedonic experience and store loyalty. ProcediaSocial and Behavioral Sciences, 130, 469-478.

Oliver, R. L. (1999). Whence consumer loyalty? Journal of Marketing, 63(4), 33-44.
Ortegón-Cortázar, L., \& Royo-Vela, M. (2017). Attraction factors of shopping centers: Effects of design and eco-natural environment on intention to visit. European Journal of Management and Business Economics, 26(2), 199-219.

Overby, J. W., \& Lee, E. J. (2006). The effects of utilitarian and hedonic online shopping value on consumer preference and intentions. Journal of Business Research, 59(10-11), 1160-1166.

Puccinelli, N. M., Goodstein, R. C., Grewal, D., Price, R., Raghubir, P., \& Stewart, D. (2009). Customer experience management in retailing: Understanding the buying process. Journal of Retailing, 85(1), 15-30. doi: 10.1016/j. jretai.2008.11.003

Ringle, C. M., Wende, S., \& Becker, J. M. (2015). SmartPLS 3. Boenningstedt: SmartPLS GmbH.

Ryu, K., Lee, H. R., \& Gon Kim, W. (2012). The influence of the quality of the physical environment, food, and service on restaurant image, customer perceived value, customer satisfaction, and behavioral intentions. International Journal of Contemporary Hospitality Management, 24(2), 200-223. doi: 10.1108/09596111211206141

Sanguanpiyapan, T., \& Jasper, C. (2010). Consumer insights into luxury goods: Why they shop where they do in a jewelry shopping setting. Journal of Retailing and Consumer Services, 17(2), 152-160. doi: 10.1016/j.jretconser.2009.12.001

Schepers, J. J., Nijssen, E. J., \& van der Heijden, G. A. (2016). Innovation in the frontline: Exploring the relationship between role conflict, ideas for improvement, and employee service performance. International Journal of Research in Marketing, 33(4), 797-817.

Sharma, A., \& Stafford, T. F. (2000). The effect of retail atmospherics on customers' perceptions of salespeople and customer persuasion: An empirical investigation. Journal of Business Research, 49(2), 183-191. doi: 10.1016/S0148-2963(99)00004-1 
Sherry, J. F., Jr., \& McGrath, M. A. (1989). Unpacking the holiday presence: A comparative ethnography of two gift stores. Association for Consumer Research, Special Volumes, 148-167.

Sheth, J. N., Mittal, B., \& Newman, B. I. (2001). Comportamento do cliente: Indo além do comportamento do consumidor. São Paulo: Atlas.

Singh, P., Katiyar, N., \& Verma, G. (2014). Retail shoppability: The impact of store atmospherics $\&$ store layout on consumer buying patterns. International journal of scientific \& technology research, 3(8), 15-23.

Solomon, M. R. Packaging the service employee. In: C. H. Lovelock, \& C. H. Lovelock. (1991). Services marketing (pp. 372-377). Englewood Cliffs, NJ: Prentice Hall.

Teixeira, J. M., \& Hernandez, J. M. da C. (2012). Valores de compra: Antecedentes e as relaçóes com os resultados do varejo. REAd-Revista Eletrônica de Administração, 18(1).

Turley, L. W., \& Chebat, J. C. (2002). Linking retail strategy, atmospheric design and shopping behaviour. Journal of Marketing Management, 18(1-2), 125-144.

Turley, L. W., \& Milliman, R. E. (2000). Atmospheric effects on shopping behavior: A review of the experimental evidence. Journal of business research, 49(2), 193-211.

Udo, G. J., Bagchi, K. K., \& Kirs, P. J. (2010). An assessment of customers'-service quality perception, satisfaction and intention. International Journal of Information Management, 30(6), 481-492. doi: 10.1016/j.ijinfomgt.2010.03.005

Van Rompay, T. J., Tanja-Dijkstra, K., Verhoeven, J. W., \& van Es, A. F. (2012). On store design and consumer motivation: Spatial control and arousal in the retail context. Environment and Behavior, 44(6), 800-820. doi: 10.1177/0013916511407309

Voss, K. E., Spangenberg, E. R., \& Grohmann, B. (2003). Measuring the hedonic and utilitarian dimensions of consumer attitude. Journal of marketing research, 40(3), 310-320.

Wolfinbarger, M. F. (1990). Motivations and symbolism in gift-giving behavior. ACR North American Advances, 17, 699-706.

Yalch, R. F., \& Spangenberg, E. R. (2000). The effects of music in a retail setting on real and perceived shopping times. Journal of Business Research, 49(2), 139-147. doi.org/10.1016/ S0148-2963(99)00003-X 


\section{Appendix A}

Research scale questionnaire

Do you know the jewelry store (store name)?

Yes/No

If the answer was "No", the survey ended here.

Have you ever bought in any of the (store name) physical stores?

Yes/No

If the answer was "No", the survey ended here.

How often do you shop at the store (store name)?

( ) Weekly

( ) Monthly

( ) Approximately every 3 months

( ) Approximately every 6 months

( ) Once a year

( ) Rarely - less than once a year

Your last purchase at (store name) was:

( ) In a mall store

( ) In a store on the street

The following questions relate to your perception of the last purchase at (store name) based on a series of adjectives. Please mark the number that best reflects your assessment:

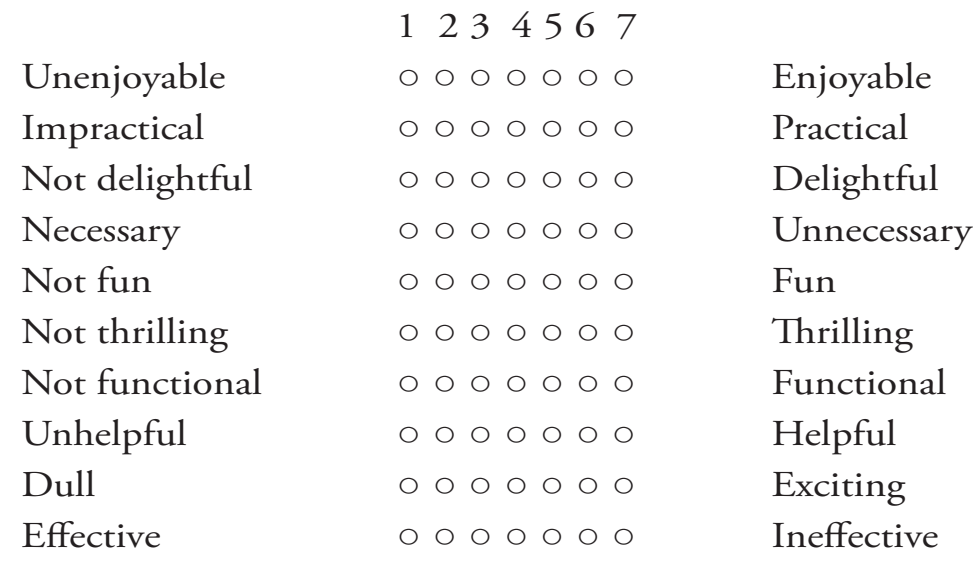

Keeping in mind the store (store name), please choose a number between 1 and 7 that best reflects your level of agreement with the following statements.

Strongly disagree Strongly agree

$\begin{array}{lllllll}1 & 2 & 3 & 4 & 5 & 6 & 7\end{array}$

The cleanliness of the outlet's floor motivates me to buy more.

Clean shelves at the retail chain outlet motivate me to stay longer.

The cleanliness of the retail chain outlet attracts me to visit again.

Listening to music creates a relaxed atmosphere while shopping. 
Music in the store motivates me to buy more.

The pleasant environment created by music makes me spend more time in the store.

An adequate rhythm of the background music makes me comfortable.

Sufficient volume of the background music makes me stay more time.

The existence of background music increases my well-being and comfort.

Keeping in mind the store (store name), please choose a number between 1 and 7 that best reflects your level of agreement with the following statements.

Strongly disagree

12
23
Strongly agree

7

The scent in the retail chain outlet encourages me to purchase more.

The scent in the store makes me revisit the retail chain outlet.

The fragrance of the retail chain outlet makes me stay more time.

The quality of the air conditioning in the store made my presence in the store comfortable.

A fully air-conditioned environment makes me comfortable while shopping.

Retail chain outlets with no air conditioning discourage me from shopping.

The lighting in retail chain outlet is fine.

The lighting in the outlet is pleasing to the eyes and makes me stay more.

A good color of lighting attracts me towards products.

The lighting of the outlet makes things more visible and attractive to me.

The lighting in the area of products allows me to evaluate the quality of the products.

The different lighting used in each area inside the store is important.

The color of the retail outlet chain is fine.

The outlet color creates a positive image in my mind.

The color of the retail outlet creates a positive perception in my mind.

I tend to buy more when I come across attractive and impressive displays.

There is a sufficient display of in-store information.

The display motivates me to look at the products more critically.

The retail chain outlet display allows me to see the displayed products clearly.

The creative and systematic arrangement of products in the retail chain outlet helps me in product selection.

As for the CUSTOMER SERVICE in (name store), please choose a number between 1 and 7 that best reflects your level of agreement with the following statements.

Strongly disagree

1

23

4

5

6

Strongly agree

Generally, the employees provide a reliable, consistent, and dependable service.

Generally, the employees are willing and able to provide the service in a timely manner.

Generally, the employees are competent (i.e. knowledgeable and skillful).

Generally, the employees are approachable and easy to contact.

Generally, the employees are courteous, polite, and respectful.

Generally, the employees listen to me and speak in a language that I can understand.

Generally, the employees are trustworthy, believable, and honest.

Generally, this facility provides an environment that is free from danger.

Generally, the employees make an effort to understand my needs.

Generally, the physical facilities and employees are neat and clean. 
Regarding your SATISFACTION with your purchase at (store name), please choose a number between 1 and 7 that best reflects your level of agreement with the following statements.

Buying the product at (store name) was one of the best things I could have done.

The product I bought at (store name) was exactly what I needed.

I am satisfied with my decision to have purchased at (store name).

I feel happy to have purchased at (store name).

Now in relation to your FUTURE INTENTIONS, please choose a number between 1 and 7 that best reflects your level of agreement with the following statements.

Strongly disagree

2

3

4

5

Strongly agree

I plan to return to this store for future purchases.

I plan to return to this store more often.

I intend to increase the value of my purchases in this store.

What is your gender?

Male / Female

How old are you?

Where do you live?

City/State

What is your marital status?

( ) Single

( ) Married

( ) Common law marriage

( ) Separated

( ) Widowed

\section{What is your level of education?}

( ) Complete elementary school

( ) Middle school

( ) Complete high school

( ) Undergraduate school

( ) College (University)

( ) Postgraduate

\section{What is your occupation?}

( ) Self-employed / Freelance

( ) Private company employee

( ) Public servant

( ) Business owner

( ) Student

( ) Other: 
Authors:

1. Ana Cristina Munaro, Master in Administration, Pontifical Catholic University of Parana, Curitiba, Brazil. E-mail: ana.munaro@pucpr.edu.br

\section{ORCID}

(iD) 0000-0002-5973-0142

2. Elaine Martins, Master in Administration, Pontifical Catholic University of Parana, Curitiba, Brazil. Email: elainemrt@gmail.com

ORCID

(iD) 0000-0003-2536-3281

3. Heitor Takashi Kato, PhD in Administration, Pontifical Catholic University of Parana, Curitiba, Brazil.E-mail: heitor.kato@gmail.com

ORCID

(iD) 0000-0001-5317-5048

\section{Contribution of each author}

\begin{tabular}{|c|c|c|c|}
\hline Contribution & Ana Cristina & Elaine Martins & Heitor Takashi \\
\hline 1. Definition of research problem & $\sqrt{ }$ & $\sqrt{ }$ & \\
\hline 2. Development of hypotheses or research questions (empirical studies) & $\sqrt{ }$ & $\sqrt{ }$ & $\sqrt{ }$ \\
\hline 3. Development of theoretical propositions ( theoretical Work ) & - & - & - \\
\hline 4. Theoretical foundation/ Literature review & $\sqrt{ }$ & $\sqrt{ }$ & \\
\hline 5. Definition of methodological procedures & $\sqrt{ }$ & $\sqrt{ }$ & $\sqrt{ }$ \\
\hline 6. Data collection & $\sqrt{ }$ & $\sqrt{ }$ & \\
\hline 7. Statistical analysis & $\sqrt{ }$ & $\sqrt{ }$ & \\
\hline 8. Analysis and interpretation of data & $\sqrt{ }$ & & $\sqrt{ }$ \\
\hline 9. Critical revision of the manuscript & & & $\sqrt{ }$ \\
\hline 10. Manuscript Writing & $\sqrt{ }$ & $\sqrt{ }$ & \\
\hline 11. Revisions suggested by reviewers & $\sqrt{ }$ & & $\sqrt{ }$ \\
\hline
\end{tabular}

\section{Erratum}

Where was written:

"Review of Business Management, São Paulo, v.21, n.5, p.788-812, oct/dec. 2019."

Now read:

“Rev. Bras. Gest. Neg. São Paulo v.21 n.4 oct-dec. 2019 p. 788-812” 